\title{
Eski Rusçada dar ünlülerin düşmesi ve Çağdaş Rusçaya etkisi
}

\section{Zulfiya ŞAHİN 1}

\begin{abstract}
APA: Şahin, Z. (2020). Eski Rusçada dar ünlülerin düşmesi ve Çağdaş Rusçaya etkisi. RumeliDE Dil ve Edebiyat Araştırmaları Dergisi, (20), 642-654. DOI: 10.29000/rumelide.792293.
\end{abstract}

\section{$\ddot{O} \mathbf{z}$}

Yaşayan her olguda olduğu gibi dilde de meydana gelen durağanlık hali dilin gelişim sürecinin bir sonucudur. Günümüz çağdaş dillerin yapısını ve işleyişini daha iyi anlamak için dili tarihsel açıdan incelemek önemlidir. Çağdaş Rusçanın durağan durumu yaklaşı 1300 yıllık umumi gelişiminin bir sonucudur ve günümüz Rusçasındaki yapısal ve işlevsel özelliklerin çoğu Rusçanın tarihsel geçmişinde saklıdır. Yapılan çalışmada, Eski Rusçanın yapısını kökünden değiştiren ve günümüz Rusçasının yapısını belirleyen dar ünlülerin düşmesi hususu araştırılmaktadır. XII.-XIII. yüzyıllarda gerçekleşen /ъ/ ve / / ünlülerinin düşmesi Eski Rusçanın sesbilimsel yapısından başlayarak biçimbirimsel ve sözcükbirimsel düzeye kadar etkisini sürdürmüştür. Sunulan çalışmada dar ünlülerin düşme sürecinin tarihsel yönü incelenerek Çağdaş Rusça üstündeki etkisi ve izleri takip edilmeye çalışılmıştır. Bu amaç doğrultusunda şimdiye dek Rusçada dar ünlülerin düşmesi üzerine yayımlanmış olan araştırmalar göz önünde bulundurularak, özgün inceleme ve taramalara dayanarak, Çağdaş Rusçada bulunan bazı ses değişimleri açıklanmaya çalışılmıştır. Bu bağlamda özellikle yabancı dil olarak Rusça öğretiminde güçlük oluşturan konular arasında yer alan /o/ $\rightarrow / \varnothing /$ ve $/ \ni / \rightarrow / \varnothing /$ değişkelerin ve dar ünlülerin düşmesi süreci arasındaki ilişki üzerinde durulmuştur. Yapılan çalışmanın yenilikçi önemi, çağdaş yabancı dil öğretiminde tarihsel dilbilgisinin ve özellikle tarihsel sesbiliminin önemini vurgulamasıdır. Günümüz yabancı dil olarak Rusça öğretiminde çoğu zaman paradigmadan sapmalar olarak tanıtılan bazı ses ve biçimbirim değişiklikleri, dilin gelişimsel bir sürecin sonucudur. Bu yaklaşım yabancı dil öğretiminde bilişsel zemini desteklemektedir.

Anahtar kelimeler: Rusça, sesbilim, sesbilgisi, dar ünlüler, tarihsel sesbilimi

\section{Loss of reduced vowels in Old Russian and effects on Modern Russian}

\begin{abstract}
As with any living phenomenon, the contemporary state of a language is a result of the development process. In order to have a better understanding of the structure and functioning of any contemporary language it is important to study the language from a historical perspective. The steady state of contemporary Russian is a result of a 1300-year-old development, and most of the structural and functional features of today's Russian are hidden in its past. The presented study is devoted to the loss of reduced vowels, which radically changed the structure of Old Russian and effected structure of contemporary Russian. The loss of / $b$ and / $\mathrm{z} /$ vowels, which took place in XII-XIII centuries, that effected the phonetical level of Old Russian later continued to influence morphological and lexical levels. This study presents an attempt to trace the effects of a historical phonetical process to modern Russian. For this purpose, the studies published on the loss of reduced vowels in Old Russian were taken in to the consideration, as well as original scans and research were made in order to explain
\end{abstract}

Doç. Dr., Ankara Üniversitesi, DTCF, Slav Dilleri ve Edebiyatları Bölümü, Rus Dili ve Edebiyatı ABD (Ankara, Türkiye), sahinz@ankara.edu.tr, ORCID ID: 0ooo-0002-6967-739X [Makale kaylt tarihi: 11.06.2020-kabul tarihi: 20.09.2020; DOI: $10.29000 /$ rumelide.792293] 


\begin{abstract}
some sound changes in Contemporary Russian. In this sense, the phonological alternations $/ o / \rightarrow / \varnothing /$ and $/ \ni / \rightarrow / \varnothing /$, which are among the subjects that cause difficulties in teaching Russian as a foreign language, are carefully studied in terms of connections to the loss of reduced vowels. The innovative significance of this work is that it emphasizes the importance of historical grammar in contemporary foreign language teaching and importance, especially, of historical phonetics. In modern teaching Russian as a foreign language, some phonological and morphological alternations are often introduced as deviations from the paradigm, but they, actually, are the result of a developmental process of language and the part of the paradigm. This approach supports the cognitive base in foreign language teaching.
\end{abstract}

Keywords: Russian, phonology, phonetic, reduced vowels, historical phonology

\title{
Giriş
}

Çağdaş bir dilin sessel yapısının özellikleri ve işleyiş kanunlarının temel ilkeleri çoğu zaman o dilin tarihsel gelişiminde saklıdır. Bu tarihsel gelişimin tabi sonucu olarak Çağdaş Rusçada meydana gelen değişimler bir istisna değildir. Eski Rusçanın tarihsel ses değişimlerinin izini sürmeden, Çağdaş Rusçanın sessel yapısını açıklamak neredeyse olanaksızdır. Günümüz Rusçasında yer alan sessel özelliklerin çoğu dilin uzun tarihsel gelişiminin bir sonucudur. Bu nedenle tarihsel sesbilgisi dil öğretiminde büyük önem teşkil etmektedir. İnsan dilinin (yapay diller hariç) en hareketli tabakası sessel katmanıdır. Zira dildeki tarihsel değişimlerin çoğu sesbilimsel düzeyden başlayarak zaman içinde dilin biçimbirimsel, ardından ise sözdizimsel düzeylerine kadar uzanır.

Yaklaşık 1000 yll önce Eski Rusçada önemli sessel değişimler gerçekleşmiş, bu sessel değişimlerin sonucunda sesbirimlerin uyumu ve dolayısıyla dilin sessel yapısı önemli ölçüde değişmiştir. Tüm

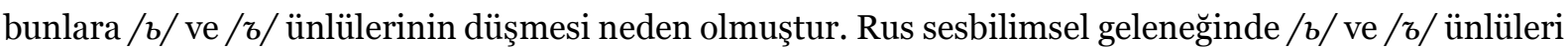
yarı oluşumlu ünlüler (Rus. гласный неполного образования) (Şahmatov, 1916: 53; İvanova, 2005: 63), dar ünlüler (Rus. редуцированный гласный) (Zaliznyak, 2004: 58; Grutso, 2004: 46) veya çok kısa ünlüler (Rus. сверхкраткий гласный) (Şahmatov, 1916: 14; Galinskaya, 2009: 47; Bernşteyn, 2005: 248) olarak adlandırılır. İngiliz sesbiliminde aynı ünlüler basically high lax vowels (Lunt 1974: 26) olarak, Almanca sesbilim geleneğinde ise überkurze laute (Brauer 1961: 111, akt. Lehfeldt) ünlüleri olarak bilinir. Eski Rusçada uzun süre önce gerçekleşen dar ünlülerin düşmesi olayının kadim izleri günümüz Çağdaş Rusçasına kadar uzanmaktadır.

"Slav dillerinin tarihçesinde dil yapılarının derin değişimine sebep olan süreçler vardır. Kanunlar hiyerarşisinde bu süreçler belirleyici ve ana etken konumundaydı... Slav dillerinin tarihçesinde II. yüzyılda başlayan dil yapısının derin değişimi dar ünlülerin düşmesiyle doğrudan bağlantılıdır" (Berşteyn, 2005: 248). "Slav dillerinin bin ylllk tarihsel gelişiminin genel çizgilerini dar ünlülerin düşmesi belirlemiştir." (Gasparov, 1974: 187). "Dar ünlülerin düşmesi sadece sesbirimlerin yok olmasına neden olmamıştır. Eski Slav dillerinin sessel yapılarının temelini de (hatta sadece sessel yapılarını da değil) değiştirmiş̧tir.” (Popov, 2015: 47). "Eski Rus çağının en önemli sesbilimsel olayıdır." (Zaliznyak, 1992: 82). Eski Rusçada dar ünlülerin düşmesi çağdaş Rus Dilbiliminde farklı kuramların ortaya çımasına neden olmuştur. Örneğin, Trubetskoy Rusça ve Ukraynaca ağızlarının ayrımını dar ünlülerin düşme sürecine dayandırmaktadır. Trubetskoy'un kuramına göre dar ünlülerin Rusya'nın kuzey ve güney bölgelerinde farklı zaman dilimlerinde düşmesi Rusça ve Ukraynaca dillerinin ortaya çıkmasına sebep olmuştur (Trubetskoy, 1987: 143). Trubetskoy'un kuramı Şahmatov'un eski yazıtların analizine dayandırılmaktadır. Şahmatov güney bölgesinde bulunan Galitsko-Volınsk ve kuzey bölgesini 
temsil eden Novgorod yazıtlarını inceleyerek dar ünlülerin güneyde yüz yıl önce düştüğünü kanıtlamıştır (Şahmatov, 1915: 229). Bernşteyn ise söz konusu sürecin ilk aşamada sadece ağız ayrımını tetiklediğini, ancak Eski Rusya'da yaşanan sonraki siyasi süreçlerin bu tetiklenen ağız ayrımının farklı dillere dönüşmesini sağladığını savunmaktadır (Bernşteyn, 2005: 41). Dar ünlülerin düşme süreci Rus dilbiliminde Zaliznyak (1993), Markov (1964), Sidorov (1966), Popov (2015) tarafından detaylı olarak tasvir edilmiştir. Sürecin kuramsal sebepleri ise Abernathy (1953), Lehfeldt ve Altmann (2002), Rusinov (1979), Levitskiy (2007) tarafından yürütülen çalışmalara konu olmuştur. Dar ünlülerin düşmesine ilk istatistiksel yorum Abernathy tarafından gündeme getirilmiştir. Abernathy (1953) Bilgi Kuramına (Entropi) dayanarak Zografsk İncilindeki hem güçlü hem zayıf konumdaki dar ünlüler için dil fazlalığı denklemiyle $\left(H=-K \Sigma_{P i} \log P_{i}\right)$ fazlalık değerlerini tespit etmeye çalışmıştır. Yapılan analizin sonucunda dar ünlülerin tam ünlülere dönüştüğü veya tümüyle düştüğü durumlarda $H$ ’nin en küçük değerlere sahip olduğunu tespit etmiştir. Böylelikle sürecin Bilgi Kuramının doğrultusunda gerçekleştiğini savunmuştur (Abernathy, 1953; akt. Lehfeldt, 2002). Rusinov (1979) dar ünlülerin düşmesinin ünlülerin kullanım sıklığıyla bağlantılı olduğunu savunmuştur. Dilbilimci /ъ/ ve /ъ/ ünlülerinin zayıf konumda, güçlü konuma kıyasla daha sık kullanıldığı, zayıf konumdaki seslerin düşmesinin ise dilin gelişimsel bir özelliği olduğu ve bu ünlülerin düşmeye "mahkûm” olduğu sonucuna varmıştır (Rusinov, 1979). Lehfeldt ve Altman (2002) dar ünlülerin düşmesini Menzerath Kuramının doğrultusunda açıklamaya çalışmıştır. Menzerath Kuramına göre: Sözcügün boyutu onu oluşturan seslemlerin boyutlarıyla doğrudan orantılıdır. Sözcük ne kadar kısa olursa, yani seslem sayısı bakımından ne kadar kısa olursa onu oluşturan seslemlerin o kadar büyük olması gerekmektedir. Eski Rusçada seslem yapısı oldukça kurallı ve sınırlıydı. Bu durum Eski Rusçada sözcüklerin çok uzun olmasına sebep olmaktaydı. Dar ünlülerin düşmesi sonucunda seslem yapısı kökünden değişmiş ve daha büyük seslemlerin oluşumuna olanak vermiştir. Böylelikle dar ünlülerin düşmesi dilin Menzerath Kuramına göre gelişimini sürdürmesine imkân tanımıştır.

\section{Çalışmanın yöntemi}

Yapılan çalışma, dar ünlülerin düşme sürecini tarihsel ekseninden değerlendirerek, sürecin Çağdaş Rusçaya etkisini ve bu etkinin izlerini sürmeye çalışan bir denemedir. Bu nedenle, sunulan çalışmada şimdiye dek Rusçada dar ünlülerin düşmesi üzerine yayımlanmış olan yapıtlarla, incelemeler göz önünde bulundurularak, özgün inceleme ve taramalara dayanarak Çağdaş Rusçada bazı ses değişimleri açıklanmaya çalışılmıştır. Sunulan çalışmayla günümüz yabancı dil olarak Rusça öğretiminde istisna olarak tanıtılan bazı ses değişikliklerinin dilin tarihçesinde yaşanan süreçlerin sonucu olduğunu göstererek bu konu hakkında bilişsel zemin oluşturmak hedeflenmiştir. Zira "Bilişsel olarak öğrenilen bilgiler uygulama düzeyinde becerilerin gelişimini olumlu yönde etkilemektedir” (Vıgotskiy, 2018: 510).

\section{Eski Rusçanın ünlüler dizgesi}

Eski Rusçanın ünlüler dizgesi Çağdaş Rusçanın ünlüler dizgesinden oldukça farklıydı. Çağdaş Rusçada güçlü (vurgulu) konumda bulunabilen altı temel ünlü vardır, bunlar: orta alçak düz /a/, arka orta yuvarlak /o/, ön yüksek düz $/ u /$, arka yüksek yuvarlak $/ y /$, orta yüksek düz $/$ bl/, ön orta düz /э/'dir. Buna karşın Eski Rusçada sekiz temel ünlü $/ a /, / o /, / u /, / y /, / b l /, / \ni /, / n /, / x /, / A /$ ve güçlü konumda bulunabilen / $\mathrm{b} /$ ve / $\mathrm{z} /$ iki dar ünlü vardı (İvanov, 2005: 65; Grutso, 2004: 32; Musatov, 2012: 55). Eski Rusçada $/ a /, / o /, / u /, / y /, / b /$ ve $/ \ni /$ ünlülerinin özellikleri günümüz Rusçasında var olan ünlülerin özellikleriyle büyük oranda örtüşmektedir. Ancak $/ \mathrm{b} /, / \mathrm{r} /, / \mathrm{r} /, / \mathrm{k} / \mathrm{ve} / A /$ ünlülerinin özellikleri oldukça farklıydı. Bunlardan özellikle $/ \AA /$ ve $/ A$ / ünlülerinin günümüz dilinde izini dahi sürmek neredeyse

S-Petersburg Sesbilim Okuluna (Ленинградская (Санкт-Петербургская) фонологическая школа - ЛФШ) göre.

Adres

Kırklareli Üniversitesi, Fen Edebiyat Fakültesi, Türk Dili ve Edebiyatı Bölümü, Kayalı Kampüsü-Kırklareli/TÜRKIYE e-posta: editor@rumelide.com
Krrklareli University, Faculty of Arts and Sciences, Department of Turkish Language and Literature, Kayalı Campus-Kırklareli/TURKEY e-mail: editor@rumelide.com 
imkânsızdır. Dil gelişimi çok karışık ve yavaş gerçekleşen bir takım dilsel zincirleme olayların sonucudur. Zira bu olaylar dilin her durağan safhasında ancak belli ve sınırlı etkiler bırakmaktadır. Günümüz Rusçasının da sessel yapısı, tek bir sesbilimsel olayın değil, tarihi süreç içerisinde gerçekleşen bir takım sesbilimsel değişikliklerin bir sonucudur. Çağdaş yabancı dil eğitimi, dinamik ve belli standartlara bağlı olan bir süreçtir. Modern yaşama uyum sağlama amacıyla geliştirilen bu standartlar çoğu zaman dilleri hem tek bir çatı altında hem de sadece belli bir eksende değerlendirme eğilimindedir. Bu yaklaşım çoğu zaman dile tarihsel ekseninden bakma olasılığı vermemektedir. Çoğu düzenli diller 3 için bu yaklaşım problem oluşturmadığı gibi tam aksine kısa sürede iyi sonuçlar elde etme imkânını vermektedir. Ancak dil paradigmalarında sapmaların yoğun olarak göründüğü bir dil için tarihsel gelişimine değinmeden başarıya ulaşmak oldukça zordur. Zira Çağdaş Rusçada ünlülerle ilgili biçimbirimsel ve sessel düzeylerde görünen sapmaların sırrı, günümüzde yok olan ancak öncesinde var olan $/ \mathrm{b} /, / \approx /, / \mathrm{r} /, / \mathrm{k} / \mathrm{ve} / A /$ ünlülerinde saklıdır.

Eski Rusçada küçük yer (Rus. ер малый) olarak adlandırılan ъ harfi dar ön orta düz olan /ъ/ sesini işaret ederdi. Bu ses dar ve zayıf /э/ sesine oldukça yakındı. Büyük yer (Rus. ep большой) olarak adlandırılan ъ harfi ise yine dar ancak arka orta düz olan / $/$ sesini belirtirdi. / $/$ sesi de /o/ ünlüsüne oldukça yakın, ancak daha zayıf ve dar bir ünlüydü. / $b /$ ve / $/$ ünlülerine Çağdaş Rusçada çeviri yazısında rastlanmaktadır. Ancak günümüz dilinde bu ünlüler sadece zayıf konumda bulunabilir, dolayısıyla birer değişke olarak kabul görür. Bununla beraber günümüz Rusçasında bu ünlüler akustik bakımından da küçük farklılık göstermektedir. Çağdaş dilde /ъ/ ön ancak orta/yüksel düz bir ünlüyü, yani / $u$ /’ye daha yakın bir ünlüyü belirtirken, /ъ/ ünlüsü orta/orta düz a-ahenkli bir sesi karşlar. Eski Rusçada / $/$ / ve /ъ/ ünlüleri güçlü konumda bulunabildiğinden dolayı temel ünlüler olarak da varlık gösterirdi.

Ünlü dizgesi bakımından Eski ve Çağdaş Rusça arasında asıl farkı $/ n /, / \pi /$ ve $/ A /$ ünlüleri oluşturmaktadır. Yat' (Rus. ять) olarak adlandırılan $n$ harfi gergin ve kapalı bir /э/ sesini veya / diftongunu işaret ederdi. Eski Slavcada / $r$ / ünlüsü ön orta düz bir sesti. Sirasıyla büyük yus (Rus. юc большой) ve küçük yus (Rus. юс малый) olarak bilinen / $/$ / ve /A/ ünlüleri ise X. yüzylla kadar Eski Rusçada var olan birer genizsil ünlüydü. / $k$ / ve / $A$ /'nin sesletimi sırasında küçük dilin aşağıya inmesi hava akımının burun boşluğundan da çlkmasına neden olurdu. Günümüz Rusçasında genizsil ünlüler artık yoktur. / $/$ / ünlüsü genizsil bir /o/ sesiydi, / / / ünlüsü ise genizsil bir / $/$ / sesiydi. Özetle / $/ \mathrm{k} / \mathrm{ve} / \mathrm{A} /$ ünlüleri /o/ ve /э/ ünlülerinden genizsillik bakımından ayrılırlardı. Yazılı dilde bu sesleri büyük yus (Rus. юс большой) olarak adlandırılan ж ve küçük yus (Rus. юс малый) olarak adlandırılan $A$ harfler karşlardı. Eski Rusçada / $/$ ve / $A$ / ünlülerinin varlığı, ünlülerin ağızsıl ve genizsil olarak ayrılmasına neden olurdu.

Özetleyecek olursak, Eski Rusçada ön/arka boyutlarında beş ön $/ u /, / b l /, / n /, / \pi /, / b /$, altı arka $/ a /$, /o/, /y/, /bl/, /A/, /ъ/; ağızsıl/genizsil boyutunda dokuz ağızsl /u/, /b//,/ro/, /ъ/, /a/, /o/, /y/, /bl/, $/ ъ /$, iki genizsil / $/ \mathrm{k} /, / A /$; temel/dar boyutunda dokuz temel $/ u /, / b l /, / n /, / \pi /, / a /, / o /, / y /, / b l /, / A /$ ve iki dar $/ ъ / / ъ /$ olmak üzere on bir ünlü vardı. Ünlü bakımından bol bir dil olan Eski Rusçada ünlülerin dile etkileri oldukça güçlüydü, zira eskiden varlık gösteren ünlüler günümüz Rusçasında birçok ses ve biçim olaylarına neden olmuştur.

\section{Eski Rusçada dar ünlülerin düşmesi}

Eski Rusçada /ъ/ ve /ъ/ ünlüleri sözcükte zayıf ve güçlü konumlarına bağlı olarak nicel özellikleri bakımından farklılık gösterirdi. Zayıf konumlarda bu ünlüler çok kısa ve güçsüz seslendirilirken, güçlü

3 Burada sapmaların ve istisnaların az olduğu diller (örneğin eklemeli diller) kastedilmektedir.

\footnotetext{
Adres $\mid$ Address 
konumlarda net ve uzun seslendirilerek temel ünlülere yaklaşırdı. Eski Rusçada / ๖/ve /ъ/ ünlüleri a) sözcük sonunda, örneğin домъ, гость, конъ sözcüklerindeki gibi; b) temel ünlü öncesinde, örneğin дъва, съпати, бърати, чъто, съто sözcüklerindeki gibi; c) güçlü konumda bulunan /ъ/ ve /ъ/ öncesi, örneğin $л \mathbf{6} ъ ц ь$ чътьъць sözcüklerindeki gibi zaylf konuma düşerdi. Bu konumlarda dar olan /ъ/ ve /ъ / çok kısa ve zayıf sesletilirdi. Ancak aynı ünlüler a) vurgu altında, örneğin кусъчъкъ, сънь, въсь sözcüklerinde olduğu gibi; b) zayıf konumda bulunan /ъ/ ve /ъ/ öncesi, örneğin отъць, кубъкъ,

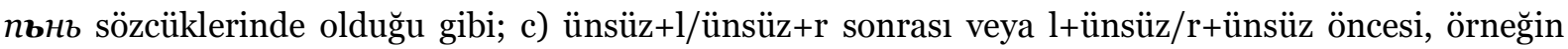
търгъ, върхъ, вълна, слъза, гърло sözcüklerinde olduğu gibi dar /ъ/ ve /ъ/ güçlü konumda bulunurdu. Bu konumda /ъ/ ve /ъ/ temel ünlüler gibi sesletilirdi. Zaman içerisinde güçlü konumda

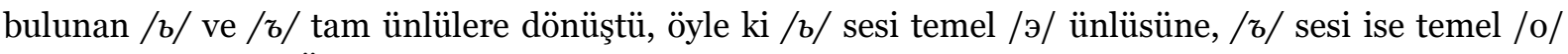
ünlüsüne dönüştü. Örneğin, кусъчькъ $\rightarrow$ кусочек, сънь $\rightarrow$ сон, въсь $\rightarrow$ ессь, отъцьь $\rightarrow$ отец, кубъкъ $\rightarrow$ кубок, пънъ $\rightarrow$ пенъ, търгъ $\rightarrow$ торг, върхъ $\rightarrow$ верх, вълна $\rightarrow$ волна, сльза $\rightarrow$ слеза, гърло $\rightarrow$ горло sözcüklerinde tam ünlüye dönüşümleri görülmektedir. Zayıf konumlarda ise $/ \mathrm{b} / \mathrm{ve} / \mathrm{\imath} /$ ünlüleri düştü, yani /ø/ (sıfır) sesine dönüştü. Örneğin: nънъ sözcüğünün yalın halinde /ъ/ ünlüsü, vurgulu ve zayıf konumda olan diğer dar ünlü öncesinde bulunduğundan dolayı güçlü konumdaydı. Zaman içinde /ъ/ ünlüsü tam oluşumlu temel /э/ ünlüsüne dönüştü ve пънь sözcüğü пень halini aldı. Ancak aynı пънь sözcüğü in-halinde Eski Rusçada пъня olarak çekimlenmekteydi ve in-halinde aynı /ъ/ ünlüsü zayıf konuma düşüyordu. Böylelikle zaman içinde zayıf konumdaki /ъ/ ünlüsü düştü, yani /ъ/'nin yerini /ø/ (sıfır) ses aldı ve пъня sözcügü̈ günümüz Rusçasında olan пня şeklini aldı. Başka bir örnek, лъбъ sözcüğünün yalın halinde / $ヶ$ / ünlüsü, hem vurgulu hem zaylf konumda olan bir diğer dar ünlü öncesinde bulunduğundan dolayı güçlü konumdaydı. Dilin gelişimi sırasında / ₹/ ünlüsü tam oluşumlu temel /o/

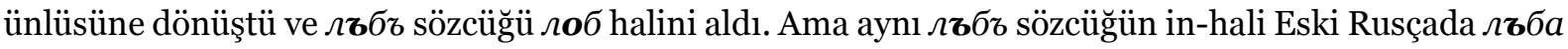

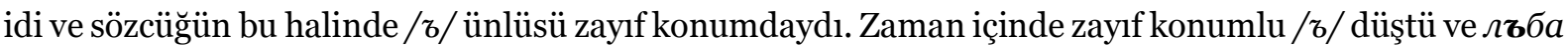

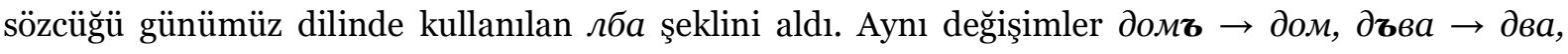
съпати $\rightarrow$ спать, бърати $\rightarrow$ брать, чвто $\rightarrow$ что, съто $\rightarrow$ сто, лъжьць $\rightarrow$ лжец, чвтьць $\rightarrow$ чтец sözcüklerinde de görülmektedir. / $/$ /ve / $ъ$ / ünlülerinin bu değişikliği Çağdaş Rusçada ancak belli gramer şekillerinde ortaya çıkan ünlülere neden oldu. Örneğin сестра-сестёр, лоб-лба, потолок-потолка, рот-рта,сон-сна, день-дни, пень-пни vd. /ъ/ve /ヶ/'nın bazı konumlarda düşmesi bazı konumlarda ise tam ünlüye dönüşmesi Rus dilbiliminde düşen (gizli) ünlü (Rus. беглый гласный) kavramını doğurmuştur. Rusçada /o/'nun bazı gramer şekillerinde düşmesi, yani /ø/ sese dönüşmesi veya aynı şekilde /э/'nın sadece belli gramer konumlarında görülmesi, diğerlerinde ise düşmesi, yani yine /ø/ sese dönüşmesi, Eski Slavcada / $b /$ ve /ъ/ ünlülerinde zaman içeresinde görünen değişikliklerin bir sonucudur. Böylelikle /ъ/ ve / $̋$ ünlülerinin Eski Rusçada varlıkları ve dil gelişimi sırasında bu ünlülerde görünen değişiklik Çağdaş Rusçada yoğun olarak yaşanan ses düşmesini açıklamaktadır.

Günümüz dilbilimi Eski Rusçada dar ünlüler neden düştü sorusuna hala cevap veremiyor. Ancak Eski Slavcada başlayıp sonrasında da Eski Rusçada devam eden ünlülerde azalma ve ünsüzlerde artma eğilimi söz konusudur. Örneğin Eski Slavcada ünlüler kısa/uzun özellikleri bakımından ayrılırdı. Ancak zaman içinde ünlülerin bu özelliği yok olmuştur. Ünlülerde bu özelliğin ortadan kalkmasına uzun ünlülerin diftonglarla kullanımındaki doğal kısalma neden olarak gösterilmektedir. Ünlülerin uzun/kısa özelliğinin yerine dar/geniş özelliğinin geliştiği düşünülmektedir. Böylelikle bazı dilbilimciler Eski Rusçada dar ünlülerin düşmesinin Eski Slavcada başlamış olan, uzun/kısa özelliğin yok olmasının bir sonucu olduğuna dair varsayımlar yürütmektedir (Şamanova vd. 2018: 32; Alekseyev 2015:70).

Dar $/ ъ /$ ve /ъ/ ünlülerinin temel ünlülere dönüşme ve düşme süreçleri dilin tarihsel gelişiminde eş zamanlı olarak gerçekleşmemiştir. Örneğin dar ünlülerin düşmesi, aynı dar ünlülerin temel ünlülere dönüşme sürecinden çok daha önce gerçekleşmiştir. Öyle ki dar ünlülerin düşmesi yoğun olarak XI.-XII. 
yüzyıllarda yaşanırken, dar ünlülerin temel ünlülere dönüşümü ise XIII. yüzyllda gerçekleşti (Musatov, 2012: 57). Bunun yanı sıra ünlülerin düşmesi süreci Rusya'nın farklı bölgelerinde farklı zamanlarda görülmüştür. Ünlülerin düşmesi güney bölgesinde yüz yll önce başlamıştır (Şahmatov, 1915: 229). Bunun yanı sıra değişimlerin veya düşmenin düzenli bir şekilde gerçekleştiğini söylemek pek de mümkün değildir. Başka bir deyişle zayıf konumda bulunan her /ъ/veya /ъ/ düşmedi. Aynı şeklide güçlü

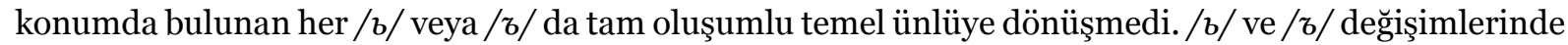
görünen düzensizliği, dilin gelişime eğilimi olduğu kadar gelenekselliğe de eğilimi olmasıyla açıklamak mümkündür. Eski Rusçada dar ünlülerin değişimi XIII. yüzyılda tümüyle tamamlanmıştır. Her ne kadar dar ünlüler XIII. yüzyılda değişimlerini sözlü dilde tamamlasalar da yazılı dilde $b$ veya $z$ harfleri varlıklarını 1917 yılına kadar "Yeni Yazım Kurallarının Yürürlüğe Girmesi” hakkındaki kararnamenin yayınlanmasına dek sürdürmüştür.

Sürecin rekonstrüktif önemi de son derece büyüktür. Öyle ki bu sürece dayanarak sözcüğün biçimini geriye giderek izlemek mümkündür. Örneğin herhangi bir sözcüğün günümüz şeklini analiz ederek Eski Rusçadaki biçimini bulmak olasıdır. Örneğin pom sözcüğünde -in; -e; -ile; -de-hallerinde veya çoğul şeklinde /o/ $\rightarrow / \varnothing /$ değişimi görünmektedir. Böylelikle Eski Rusçada bu sözcükte dar /ъ/ sesin var olduğu kanısına varmak mümkündür. Ancak başka bir sözcükte, örneğin год sözcüğünde ünlü düşmesi görünmemektedir. Böylelikle гod sözcüğündeki /o/ ünlüsünün kökeninin temel /o/ ünlüsüne dayandığı sonucuna varmak mümkündür. Aynı şekilde мизинец sözcüğünün çekimine bakarak /э/ ünlüsünün Eski Rusçadaki köküne ulaşmak mümkündür. Çekim sırasında bazı gramer şekillerde düşen /э/ dar /b/ sesinin değişkesidir. Buna karşın дело sözcüğündeki /э/ sesi sözcüğün her gramer şeklinde varlığını korumaktadır. Bu durum /э/'nin temel /э/ veya /ъ/ sesinden türediğini göstermektedir.

Günümüz Rusça dilbilgisi anlatımında, özellikle yabancı dil olarak Rusça öğretiminde, bu konu üzerinde genellikle fazla durulmaz. $/ \mathrm{o} / \rightarrow / \varnothing /$ veya $/ \ni / \rightarrow / \varnothing /$ ses değişikliği ve bunu takip eden biçimbirim değişikliği istisna olarak açıklanır. Ancak dilde oldukça yoğun görünen $/ 0 / \rightarrow / \varnothing /$ veya $/ \ni / \rightarrow / \varnothing /$ ses değişikliğinin basit istisna kavramıyla açıklanması mümkün olmadı̆̆ı gibi metodolojik olarak da doğru değildir.

Çağdaş Rusçada görünen $/ 0 / \rightarrow / \varnothing /$ veya $/ \ni / \rightarrow / \varnothing /$ ses değişikliği kuşkusuz dil gelişiminin bir sonucu ve özünde tarihsel bir olaydır. Ancak bu süreçte en fazla dikkat çeken durum $/ \mathrm{o} / \rightarrow / \varnothing /$ veya $/ \ni / \rightarrow / \varnothing /$ ses değişikliğinin Rusçaya XIII. yüzyıldan sonra giren sözcüklerde de görülmesidir. XI.-XIII. yüzyllarda Rusçanın hazinesini oluşturan sözcüklerde bu sürecin görülmesi doğal, ancak dile XVIII-XIX yüzyllarda giren sözcüklerde görülmesi ise ilgi çekicidir. Örneğin кокетка sözcüğü Rusçaya XVIII. yüzyılda Fransızcadan (Fr. la coquette) geçen bir sözcüktür (Çernıh, 2004: 409). Ancak aynı ses düşme süreci bu sözcükte de görülmektedir: кокетøка-кокеток. Başka bir örnek, марка sözcüğü Rusçaya yine Fransızcadan (Fr. la marque) XIX. yüzyllda geçmiştir (Çernıh, 2004: 511) ve ses düşmesi bu sözcükte de görülmektedir: марøка - марок. Aynı süreç XVII. yüzyılda Almancadan geçen танец (Al. der tanz) sözcüğünde de görülmektedir: танец - танøц̧а (Çernıh, 2004(2): 229). Çağdaş Rusçada bu tür örneklerin sayıca çok olması sessel bir süreç olan $/ 0 / \rightarrow / \varnothing /$ veya $/ \ni / \rightarrow / \varnothing /$ ses değişikliğinin bir noktada sessel düzeyden biçimbirimsel düzeye aktarıldığının, böylelikle dilbilgisel nitelik kazandığının bir kanitıdır.

Çağdaş Rusçada /o/ $\rightarrow / \varnothing /$ veya $/ \ni / \rightarrow / \varnothing /$ ses değişikliği belli gramer şekillerinde daha düzenli olarak görünmektedir. /o/ veya /э/ seslerin düşmesi çok sayıda isim ve sıfat gövdelerinde görülmektedir. Bu sürecin diğer bir özelliği /o/ veya /э/ seslerinin çoğu gramer yapılarında düştüğü, ancak sadece bazı gramer yapılarında varlığını koruyabildiği durumdur. Örneğin: bir isim olan pom sözcüğünün Rusçada 
rastlanan gramer şekilleri aşağıdaki gibidir: pom, pøта, pøтy, pom, pøтом, (во) pømy/(o) pøтe, рøты, рøтов, рøтам, рøты, рøтами, (во) рøтах'tır. Rusçada bulunan bu sözcüğün on üç gramer şeklinden sadece iki gramer şeklinde /o/ ünlüsü kendi varlığını korumuş, geri kalan on bir gramer şeklinde düşmüştür. /o/ veya /э/ ünlülerin korunması eğilimi daha çok ø(sıfir) son eke sahip eril isimlerin yalın tekil şekillerinde, örneğin мешок, ancak мешøка, мешøsкy уа da отец, ancak отøца, omøuy. Aynı şekilde /o/ veya /э/ ünlülerinin nötr ve dişil sözcüklerin çoğul in-hal yapılarında korunduğu görülmektedir, örneğin: сестøра - сестёр, кишøка - кишок, кольøио - колец, сутпки - суток vb. Nitel sıfatların kısa eril şekillerinde, örneğin: сильøный - силён - сильна, умøный умён - умна gibi sözcüklerde /э/ ünlünün korunduğu görülmektedir. Çağdaş Rusçada /o/ veya /э/ ünlülerinin kendi varlıklarını aynı kökten türemiş sözcüklerin hepsinde korumadığı, akraba sözcüklerinin ancak bazılarında koruduğu da görünmektedir. Başka bir deyişle aynı kökten türetilmiş farklı sözcük türlerinde (isim, fiil, sıfat vd.) veya farklı anlama sahip aynı tür sözcüklerinde farklı kullanım söz konusudur. Örneğin: игøла - игольный, иголка; очøки - очочки; сøто - сотый, сотня; кораббль - корабельный, корабельщзик; польøза - полезный. Burada Rusçanın sessel yapısında /o/ ünlüsünün sadece artdamaksıllaşmış ünsüzlerden sonra gelebildiği durumu dilin bir diğer özelliğidir, örneğin лапоть - лапøтя, котёнок - котенøка; банок - банøка, пушинок - пушинøка, дочурок - дочурФка, кухонь - кухФня, окон - окФно, суток - сутФки, носилок - носилФки; громок - громøкий, близок - близбкий vd. /э/ sesi ise sadece damaksllaşmış veya $u$, ж, u ünsüzlerinden sonra gelebilir, örneğin мизинец - мизинбца, дятел - дятбла, ветер - ветøра, парень - парбня, Павел - Павбла, комочек - комочбка; песен - песбня, башен - башбня, крышек - крышбка, лампочек - лампочбка, клёцек - клёцбка, пятен - пятбно, полотенец - полотенбце, перышек - перышбко, вкусен - вкусбный, важен - важбный vd.

Rusça ses tarihinde /ъ/ ve /ъ/ ünlüleri değişimi günümüz dilinde sadece $/ 0 / \rightarrow / \varnothing /$ veya $/ \ni / \rightarrow / \varnothing /$ ses/biçimbirim değişikliğine neden olmamıştır. Dar ünlülerin düşmesi dilin yapısını önemli ölçüde etkilemiştir. Böylece bu sürece bağlı olarak Rusçada bir takım zincirleme sessel süreçler yaşanmıştır. Ancak diğer sessel süreçlere değinmeden önce Eski Rusçanın seslem yapısını incelemekte yarar vardır. Çünkü dar ünlülerin düşmesi neticesinde ortaya çıkan sessel değişimler seslem yapısıyla doğrudan ilişskilidir.

\section{Eski Rusçanın seslem yapısı}

Eski Rusçada seslemlerin yapısı Çağdaş Rusçadaki seslem yapısından oldukça farklıydı. Öyle ki Eski Rusçada seslemlerde açık seslem kuralı ve iki seslem türü vardı: ünsüzle başlayan açık seslem ve sadece ünlüden oluşan seslem; yani ünlüyle başlayan açlk seslem. Buna karşın Çağdaş Rusçada dört seslem türü vardır: ünsüzle başlayan açık seslem, ünsüzle başlayan kapalı seslem, ünlüyle başlayan açık seslem ve ünlüyle başlayan kapalı seslem. Eski Rusçada seslemlerin ikinci özelliği yükselen ötümlülük doğrultusunda oluşmasıdır. Başka bir deyişle seslemde seslerin ötümlülük bakımından artarak dizilmesidir. Çağdaş Rusçada bu kural tümüyle korunmasa da genel eğilim olarak devam etmektedir. Eski Rusçada seslemlerin üçüncü özelliği ünlü/ünsüz uyumudur. Öyle ki damaksıllaşmış ünsüzleri sadece ön ünlüler, artdamaksıllaşmış ünsüzleri ise sadece arka ünlüler takip edebilirdi. Bu kuralı bozan sessel birleşimlerde uyum yönünde sessel değişiklikler meydana gelirdi. Örneğin ногa sözcüğü Eski Rusça seslem kurallarına, yani ünlü/ünsüz uyum kurallarına göre türetilmiştir, ancak çekim sırasında e-halinde / / / ünsüzünden sonra çekim kuralı gereği / $r$ / ünlüsü geliyordu. Bu durum ünlü/ünsüz uyumunu bozmaktaydı. Çünkü Eski Rusçada /2/ ünsüzü daimî ardamaksıllaşmış bir ünsüzdü. /no/ eki ise ön ünlüydü. Uyum gereği Rusçada /ə/ ünsüzü yerini /з/ünsüzü almıştır: нога-нозъ. 


\section{Dar ünlülerin düşmesinin sonuçları}

Dar ünlülerin düşmesi Rusçanın sessel yapısının temelinden değişmesine neden olmuştur. Süreç, dilin ses düzeyinde kalmayıp biçimbirimsel ve sözcüksel düzeylerine kadar etkisini sürdürmüştür. Bunun yanı sıra dar ünlülerin düşmesini izleyen sesbilimsel süreçler sözcüklerin köklerini de değiştirerek akraba sözcükler arasındaki bağın kopmasına da neden olmuştur. Alekseyev (2015), Grutso (2004), Şamanova (2018), Musatov (2012) dar ünlülerin düşmesi sonucunda Rusçanın sesbilimsel düzeninde aşağıdaki gibi değişiklikler meydana geldiğini savunmaktadır:

- Dar ünlülerin düşmesi sonucunda Rusça ünlüler dizgesinin sayısı iki ünlü azalmış oldu.

- Ünlüler dizgesinde /o/ ve /э/ ünlülerinin /ø/ değişkesi ortaya çımış oldu.

- Eski Rusçada var olan açık seslem kuralı ortadan kalktı. Eski Rusçada seslem mutlaka ünlüyle bitmeliydi. Ancak dar ünlülerin düşmesi neticesinde Eski Rusçada kapalı seslemler oluştu ve açık seslem kuralı yok oldu. Örneğin: $\partial ъ|н ъ| \rightarrow \partial е н ъ|, с ъ| н ъ|\rightarrow с о н|, \partial о|\mathcal{~}| \rightarrow \partial о м|, б е| р е|г ъ|$ $\rightarrow$ бe|peə|.

- Dar ünlülerin düşmesi Eski Rusçada mümkün olmayan ünsüzlerin ikizleşmesine ve ünsüzlerin yığılmasına neden olmuştur. Örneğin: günümüz Rusçasında русскиŭ sözcüğündeki $c c$ ikizleşmesi dar ünlülerin düşmesinin bir sonucudur: русъскыи $\rightarrow$ русский, аугіса съдесь $\rightarrow$ сдесь, пътица $\rightarrow$ птица, метьла $\rightarrow$ метла, стьлать $\rightarrow$ стлать, мьдльнъ $\rightarrow$ медленный gibi sözcüklerde görünen ünsüz yığılması da aynı sürecin sonucunda ortaya çıkmıştır.

- Eski Rusçada dar ünlülerin düşmesi, yukarıda da belirtildiği gibi, ünsüz yığılmasına neden olmuştur. Yan yana gelebilen ünsüzlerin arasında etkileşim gerçekleşebiliyordu. Komşu ünsüzler oluşum özellikleri bakımından birbirine benzeyebildiği gibi farklı özellikler de kazanabiliyordu. Bu süreçlerden bazıları zaman içinde yazılı dilde karşlık bulurken, bazıları sadece sözlü dilde varlıklarını sürdürmeye devam etmiştir. Sesletimi önemli ölçüde zorlaştırabilen ünsüzler yığılmasında doğal olarak en sık görünen süreç benzeşme süreci olmuştur. Rusçada ünsüz yığılmasında en sık görünen benzeşme türü gerileyici (Rus. регрессивная) yarı (Rus. неполная) benzeşmedir (Rus. ассимиляция). Rusçada gerileyici yarı benzeşme ötümlülük/ötümsüzlük veya damaksıllaşma/artdamaksıllaşma özellikleri bakımından benzeşir. Örneğin лодъка $\rightarrow$ лодка $\rightarrow$ ло[тк]а, ложька $\rightarrow$ ложка $\rightarrow$ ло[шк]а sözcüklerinde gerileyici ötümsüzleşme görülmektedir. Молотьба $\rightarrow$ молотьба $\rightarrow$ моло[Ә’б]а, съдьлати $\rightarrow$ сделать $\rightarrow$ [зд]елать gibi sözcüklerinde ise gerileyici ötümlüleşme süreci söz konusudur. Damaksıllaşma bakımından benzeşme sürecini cътихати $\rightarrow$ стихать $\rightarrow$ [c'm']uхать gibi örnekte görmek mümkündür. Artdamaksllaşma süreci ise тьмьный $\rightarrow$ темный $\rightarrow$ те[мн]ый sözcüğünde mevcuttur. Her ne kadar Rusçada en sık görünen benzeşme yarı benzeşme olsa da tam benzeşme örneklerine de rastlanmaktadır. Örneğin: cъuumu $\rightarrow$ сиить $\rightarrow$ [u:]ить, съжати $\rightarrow$ сжати $\rightarrow$ [ж:]ать sözcüklerinde tam benzeşme süreci görülmektedir.

- Dar ünlülerin düşmesi, dolaylı olarak Rusçadaki ünsüzlerde benzeşmeme durumunu ortaya çıkarmıştır. Ancak benzeşmeme süreci benzeşme sürecine kıyasla dilde fazla gelişim gösterememiştir. Benzeşmeme sürecine çok sık rastlanmasa da örnekleri mevcuttur. Bu süreci вельблудъ $\rightarrow$ верблюд, мякъкъ $\rightarrow$ мягок, слобода $\rightarrow$ свобода gibi sözcüklerde gözlemlemek 
mümkündür. Benzeşmeme süreci Rusçada patlamalı + sonor, örneğin: чuтло $\rightarrow$ чи[сл]о, patlamalı + patlamalı, örneğin: легъкый $\rightarrow$ ле[хк]иŭ, kapantılı-sürtünmeli + genizsil, örneğin: коньчьно $\rightarrow$ коне[шн]о gibi üç ünsüz yığılma türünde görülmektedir ve bu da yukarıda belirtildiği gibi dar ünlülerin düşmesinin bir sonucudur.

- Dar ünlülerin düşmesi sonses konumundaki ötümlü ünsüzlerin ötümsüzleşmesine neden olmuştur, зжбъ $\rightarrow$ зуб $\rightarrow$ зу[n], плоугъ $\rightarrow$ плуг $\rightarrow$ плу[к], морозъ $\rightarrow$ мороз $\rightarrow$ моро[c] sözcüklerinde görünen sonses değişikliği bunun örneğidir. Rusçada sonses ünsüzlerin ötümsüzleşmesine dair farklı kuramların temelinde mutlaka dar ünlülerin düşmesi süreci yer almaktadır.

- Dar ünlülerin düşmesi Rusçada dolaylı olarak / $\phi /$ sesinin oluşmasına sebep olmuştur. Dar ünlüler düşmeden önce Eski Rusça ses dizgesinde $/ \phi$ / sesi yoktu. Sonses konumdaki / $/$ / sesinin ötümsüzleşmesi veya içses konumdaki benzeşmesi / $\phi /$ sesinin ortaya çıkmasına neden olmuştur. İlk olarak sadece sesbilimsel süreçlerin değişkesi olarak ortaya çıkan $/ \phi$ / sesi dilin gelişimiyle beraber Rusçada bağımsız sesbirim konumuna kadar gelişim göstermiştir.

- Dar ünlülerin düşmesi sonucunda oluşan ve ilk olarak sadece sonses konumunda bulunabilen artdamaksıllaşmış / $\phi$ / sesi zaman içeresinde içses/orta ses olarak da kullanılmaya başlamıştır. İç konumdaki kullanım neticesinde artdamaksıllaşmış $/ \phi$ / sesinin damaksıllaşmış / $\phi$ '/ karşıllı̆̆ gelişmiştir. Günümüz Rusça ses dizgesinde / $\phi /$ ve $/ \phi^{\prime}$ / ünsüzleri bağımsız sesbirimleri olarak varlık göstermektedir.

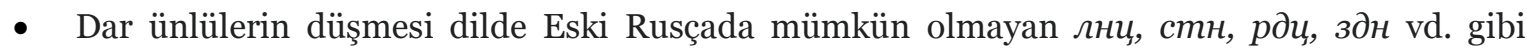
sesletimi zor ünsüz yığılmalarına sebep olmuştur. Üç, dört veya beş ünsüzden oluşan yığılmalarda zaman içinde sesletimi kolaylaştırmak amacıyla ses düşmesi süreci görülmeye

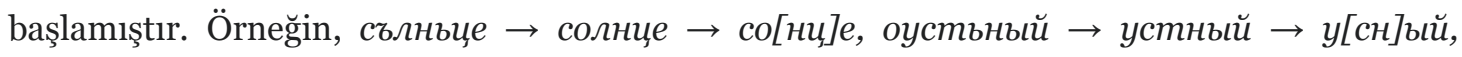
мъстьный $\rightarrow$ местный $\rightarrow$ ме[сн]ый, праздьный $\rightarrow$ праздный $\rightarrow$ пра[зн]ый, сьрдьце $\rightarrow$ сердие $\rightarrow$ се[ри]е, поздьно $\rightarrow$ поздно $\rightarrow$ по[зн]о vd. Ses düşmesi sonucunda meydana gelen değişimlerden bazıları yazılı dile yansımış, bazıları ise sadece sözlü dilde varlıklarını sürdürmüştür. Yazılı dile yansımış değişimler zaman içinde etimolojik bağlantıların kopmasına neden olmuştur, kimi biçimbirimlerin türedikleri köklerinin izini sürmek neredeyse imkânsız olmuştur. Örneğin Rusya'nın Tambov ve Ryazan bölgelerinde akan Цна nehri vardır. Günümüz Цна adında Дьсна sözcüğünün kökünü görmek oldukça zordur. Дьсна nehri akarak daha büyük bir nehir olan Ока'le birleşir ve Ока'nın să̆ kolunu oluştururdu. Дьсна kendi adını ise Eski Rusçada sağ kol anlamına gelen десниц̧a sözcüğünden almıştır. Zaman içinde zayıf konumda bulunana dar /ъ/ düştü ve Дсна sözcüğü meydana geldi. Daha sonraki gelişimlerde ötümlü / / ünsüzü ötümsüz / $/$ / önünde gerileyici benzeşmenin sonucunda $/ \mathrm{m} /$ 'ye dönüştü ve böylelikle Тсна sözcügü türetildi. Rusçada kapantılı $/ \mathrm{m} /$ ve sürtünmeli / $\mathrm{c} /$ birleşerek kapantılısürtünmeli $/ u /$ sesini oluşturur. Böylelikle bir takım sesbilimsel süreçler ve sessel değişimler sonucunda Дьсна adlı nehir günümüz dilinde Цна şeklini aldı (Musatov, 2012: 58). Başka bir örnek: Rusya’nın güneybatısında Брянск adlı bir şehir vardır. Günümüz Брянск sözcüğünde Дъбрянъскъ sözcüğün izini sürdürmek zor, ancak imkânsız değildir. Öyle ki Дъбрянъскъ kendi adını bulunduğu bölgenin özelliklerinden almıştır. Eski Rusçada дъбрь sözcüğü sıkı, el değmemiş orman anlamını taşırdı, hatta aynı anlam Çağdaş Rusçada da korunmuştur. Dar ünlülerin düşmesi sonucunda Дъбряньскъ sözcügü Дбрянск şeklini almıştır. Zaman içinde 
sözcük başındaki iki patlamalı ünsüzden ilki olan $/ \partial /$ ünsüzü düşmüş ve günümüz dilinde kullanılan Брянск sözcüğü meydana gelmiştir (Musatov, 2012: 59).

- Dar ünlülerin düşmesi, Rusçanın sessel yapısında / $\sigma-n /, / \sigma^{\prime}-n^{\prime} /, / \beta-\phi /, / \beta^{\prime}-\phi^{\prime} /, / \imath-\kappa /$, $/ \iota^{\prime}-\kappa^{\prime} /, / \partial-m /, / \partial^{\prime}-m^{\prime} /, / 3-c /, / 3^{\prime}-c^{\prime} /, / \mathcal{c}-u /$ şeklinde düzenli ötümlü/ötümsüz ünsüz karşıllkların oluşmasına neden olmuştur. İleriki gelişimler sonucunda ise Rusçada ötümlü/ötümsüz özellik bakımından ünsüz sesbirimlerin güçlü ve zayıf konumları belirlenmiştir.

- Dar ünlülerin düşmesi sonucunda Rusçada ünsüzlerin damaksıl/ artdamaksıl özelliği konumsal nitelikten bağımsız niteliğe dönüşmüştür. Eski Rusçada ünsüzlerin damaksıl/ artdamaksıl özelliklerini ardışık ünlüler belirlerdi, ancak dar ünlülerin düşmesi bu özelliğe anlam ayırt edici niteliği kazandırmıştır, örneğin кон [кон] - конь [кон'], брат [брат] - брать [брат'], кров [кроб] - кровь [кроф'] vd. Böylelikle, dar ünlülerin düşmesi Rusçanın sessel yapısında / 6 $\sigma^{\prime} /, / n-n^{\prime} /, / \partial-\partial^{\prime} /, / m-m^{\prime} /, / c-c^{\prime} /, / 3-3^{\prime} /, / \beta-\theta^{\prime} /, / \phi-\phi^{\prime} /, / \mu-\mu^{\prime} /, / \Omega-\Omega^{\prime} /, / \mathcal{M}-\mathcal{M}^{\prime} /$, $/ p-p^{\prime} /, / \kappa-\kappa^{\prime} /, / 2-2^{\prime} /, / x-x^{\prime} /$ şeklinde düzenli damaksıl/artdamaksıl karşllılara neden olmuştur.

- Dar ünlülerin düşmesi Rusçanın tüm ağızlarında sonses $/ M^{\prime} /$ sesbiriminin artdamaksıllaşmasına neden olmuştur. Çağdaş Rusçada: a) şimdiki ve basit gelecek zamanda 1. tekil şahıs çekim eklerinde, örneğin дати $\rightarrow$ $а а_{м ь} \rightarrow \partial а м$; b) eril ve nötr isimlerin, sıfatların ve zamirlerin tekil -ile halinde, örneğin столъмь $\rightarrow$ столом, сынъмь $\rightarrow$ сыном, новымь $\rightarrow$ новым, темь $\rightarrow$ тем, моимь $\rightarrow$ моим; c) eril ve nötr sifatların ve zamirlerin tekil -de halinde, örneğin новомь $\rightarrow$ новом, томь $\rightarrow$ том vb. sözcüklerde ölçünlü sesletim kurallarına göre $/ M^{\prime} /$ 'nin sadece $/ \mathcal{M} /$ şeklinde artdamaksıllaşmış sesletimi kabul görmektedir. $/ \mathcal{M}$ '/ sesbirimi sonses konumdaki damaksıllaşmış şeklini sadece sık kullanılan başka gramer şekilleriyle desteklendiği sözcüklerde koruyabilmiştir, örneğin семь $\rightarrow$ семи $\rightarrow$ семью, восемь $\rightarrow$ восьми $\rightarrow$ восъмью.

- Dar ünlülerin düşmesi sonucunda artdamaksıllaşmış önek ardından gelen / $u$ / sesi /bl/ sesine dönüştü, örneğin: съиграти $\rightarrow$ сиграти $\rightarrow$ сыграть.

Dar ünlülerin düşmesi sonucunda Rusçanın biçimbirimsel ve sözcüksel düzenlerinde aşağıdaki gibi değişiklikler meydana gelmiştir (Alekseyev 2015; Grutso (2004); Şamanova 2018; Musatov 2012):

- Dar ünlülerin düşmesi sözcüklerin kısalmasına neden olmuştur. Eski Rusçada dar ünlüler hem zayıf hem güçlü konumlarda seslem oluşturabiliyordu. Ünlülerin düşmesi seslemin ortadan kalkmasına neden olmuştur. Sözcüklerde sadece tam oluşumlu temel ünlüler veya güçlü konumda olan dar ünlüler kaldığından dolayı seslem sayısı önemli ölçüde azalmış oldu. Sözcükler tek sesbilimsel süreç sonucunda birden fazla seslem kaybetti. Örneğin: $в$ ъ $|з \partial o| p ъ \rightarrow$ вздор $\mid$ (üç seslem $\rightarrow$ bir seslem); ль $\mid$ съ $\mid$ ны $|u| \rightarrow$ лес|ной| (dört seslem $\rightarrow$ iki seslem); съ $\mid$ про $|c ъ| н ъ|\kappa ъ| \rightarrow$ спро $\mid$ со $\mid$ нок $\mid$ (beş seslem $\rightarrow$ üç seslem). Sözcükteki seslem sayısının azalması tek seslemli sözcüklerin türemesine neden olmuştur. Örneğin: $c a|\partial ъ| \rightarrow c a \partial|; \mathcal{M z}| x ъ \mid$ $\rightarrow \mathcal{M о х}|; \partial о| \mathcal{)}|\rightarrow \partial о м| ; \partial ъ|н ъ| \rightarrow \partial е н ъ|; с ъ| н ъ \mid \rightarrow$ сон $|, \kappa ъ| т о|\rightarrow \kappa m o| v d$.

- Dar ünlüleri düşmesi sonucunda damaksıllaşmış ve artdamaksıllaşmış ünsüzler aynı seslemde varlık göstermeye başlamıştır, örneğin: мr xъ $\rightarrow$ мex (damaksıllaşmış ünsüz + ön ünlü + 
artdamaksıllaşmış ünsüz); лґьcь $\rightarrow$ лec (damaksıllaşmış ünsüz + ön ünlü + artdamaksıllaşmış ünsüz); львъ $\rightarrow$ лев (damaksıllaşmış ünsüz + ön ünlü + artdamaksıllaşmış ünsüz). Böylelikle Eski Rusçada var olan ses uyumu ortadan kalkmış oldu.

- Dar ünlülerin düşmesi sonucunda sadece ünsüzlerden oluşan yeni biçimbirimler türemiştir, örneğin, ön ek вс: въспати $\rightarrow$ вспять, въсадити $\rightarrow$ всадить; ӧn ek вз: възити $\rightarrow$ взойти, възати $\rightarrow$ взять, възрасти $\rightarrow$ взрасти; уарı еkі ск: руську $\rightarrow$ русскую, Полотьськъ $\rightarrow$ Полоцка; sıfir son ek (ø): грп хъ $\rightarrow$ грех, впкъ $\rightarrow$ век, вечеръ $\rightarrow$ вечер.

- Dar ünlülerin düşmesi Rusçada $/ o / \rightarrow / \varnothing /$ veya $/ \ni / \rightarrow / \varnothing /$ değişkesine, başka bir deyişle düşen (gizli) ünlü olayına neden olmuştur. Analojik benzetmenin sonucunda düşen (gizli) ünlü olayı etimolojik olarak dar ünlülere sahip olmayan sözcüklerde de ortaya çıkmaya başlamıştır, böylelikle $/ o / \rightarrow / \varnothing /$ veya $/ \ni / \rightarrow / \varnothing /$ değişkesi Rusçaya gramer özellik olarak yerleşmiştir, örneğin парк $\rightarrow$ парка, марка $\rightarrow$ марок, сабля $\rightarrow$ сабель, вишня $\rightarrow$ вишен vd. Dilin ileriki gelişim süreçlerinde düşen (gizli) ünlü biçimbirim düzeyine yansıyarak bazı yapı eklerinde düzenli değişkelere neden olmuştur. Örneğin, yapı ek -ец/ц: свинец $\rightarrow$ свинца, испанец $\rightarrow$ испанца, кореец $\rightarrow$ корейца; уарı eki -ок/к: брелок $\rightarrow$ брелка, бросок $\rightarrow$ броска; уарı eki -к/ек: букашка $\rightarrow$ букашек, бумажка $\rightarrow$ бумажек; yapı eki -онок/онк: тигрёнок $\rightarrow$ тигрёнка, слонёнок $\rightarrow$ слонёнка.

- Çağdaş Rusçada geçmiş zamanında bazı eril fiillerde görünen kısalmalar aynı sürecin sonucudur, örneğin неслъ $\rightarrow$ нес $\Omega \rightarrow$ нес, гръблъ $\rightarrow$ гребл $\rightarrow$ греб, замьрлъ $\rightarrow$ замерл $\rightarrow$ замер vd. Bu grup sözcüklerde dar ünlülerin düşmesi sonucunda sözcügün sonunda ünsüz yığılması oluşmuş, bu da zaman içinde sonsesin düşürülmesine neden olmuştur.

Dar ünlülerin düşmesi Eski Rusçanın ses ve biçimbirim yapısında önemli değiş̧ikliklere neden olmuştur. Yukarıda sıralanan sonuçlar da sürecin önemini destekler niteliktedir. Kronolojik olarak farklı zaman dilimlerinde gerçekleşen bu değişiklikler günümüze kadar ulaşmış çok sayıdaki Rusça tarihsel yazılı materyalle desteklenmektedir. Bu materyalleri inceleyerek söz konusu sürecin, daha önce de belirtildiği gibi, dilde her zaman düzenli değişikliklere neden olmadığı kanısına varmak mümkündür. Şamanova ve Talitskaya (2018: 34) görünen sapmaların geleneksel Kilise Rusçasına bağlı olduğunu savunmaktadır. Araştırmacılara göre kilise okumalarında sesletimin uzatılması geleneği dar ünlülerin zayıf konumlarda da uzun okunmasına neden olup düşmelerini engellemiştir. Popov (2015: 51) rastlanan sapmaların yazarların yaptığı hatalardan kaynaklanabildiğini ve devamında bir yazıttan başka yazıtta aktarılabildiğini belirtmektedir. Şahmatov (1915: 64) ve Goloskeviç’in (1914: 24) konuya yorumları, düzensizliklerin o dönemde geliştirilen grafik yöntemin bir sonucu yönündedir. Dönem yazarları dar ünlülerin güçlü ve zayıf konumlarını belirtmek için grafik yöntemini başvurabildiklerini düşündürmektedir.

\section{Sonuç}

Eski Rusçada XII. - XIII. yy. gerçekleşen dar ünlülerin düşmesi dili sessel ve biçimbirimsel düzeylerini önemli ölçüde değiştirmiştir. /ъ/ ve /r/'nin düşmesi Rusçada ünlü sesbirimlerinin azalmasına, yeni tip seslemlerin oluşmasına, ünsüzlerin dizgesinde ikizleşme veya yığılma gibi süreçlerin ortaya çıkmasına, ünsüzlerin damaksıllaşmış/artdamaksıllaşmış veya ötümlü/ötümsüz gibi özellikler bakımından benzeşmelerine, sonses konumdaki ünsüzlerin ötümsüzleşmesine, $/ \phi /$ ve $/ \Phi^{\prime} /$ seslerin oluşmasına, ünsüzlerin düşmesine, ünsüzler dizgesinde ötümlü/ötümsüz ve damaksıllaşmış/artdamaksıllaşmış 
özellikler bakımından düzenli karşılıkların oluşmasına vb. gibi dilbilimsel süreçlere neden olmuştur. Ayrıca dar ünlülerin düşmesi Rusçada sözcüklerin kısalmasına, yeni biçimbirimlerinin ve tek seslemli sözcüklerin oluşmasına da sebep olmuştur.

Çă̆daş Rusçanın önemli konularından biri olan ve özellikle yabancı dil olarak Rusça öğretiminde güçlük oluşturan konular arasında yer alan $/ \mathrm{o} / \rightarrow / \varnothing /$ ve $/ \ni / \rightarrow / \varnothing /$ değişkelerin anlatımı paradigmayı bozan istisnalar olarak tanıtılması bilişsel yaklaşımla çelişkiye düşmektedir. Konuya tarihsel sesbilim ekseninden yaklaşılması, başka bir değişle kadim Rusçanın tarihsel gelişimine ışık tutarak anlatılması bilişsel yöntem açısından olumlu etki oluşturma potansiyelindedir. Böylelikle $/ \mathrm{o} / \rightarrow / \varnothing /$ ve $/ \ni / \rightarrow / \varnothing /$ değişkelerin dilbilgisel paradigmadan sapmalar olarak değil, paradigmanın bir kıstası olarak değerlendirilmesini sağlamaktadır. Bu yaklaşım temelinde dilbilgisel paradigmaların sadece yatay verilerden oluşmadıklarını, dilin tarihsel gelişiminin bir sonucu olan dikey verilerin da paradigmaya entegre olabildiğini anlamak için güzel bir örnek teşkil etmektedir.

\section{Kaynakça}

Alekseyev A.V. (2015). İstoriçeskaya grammatika russkogo yazıka. Moskva: Yurayt.

Bernşteyn, S. B. (2005). Sravnitelnaya grammatika slavyanskih yazıkov. Moskva: MGU.

Brauer, H. (1961). Slavische Sprachwissenschaft, Lautlehre. Berlin.

Galinskaya, Ye. A. (2009). İstoriçeskaya fonetika russkogo yazıka. Moskva: MGU.

Gasparov, B.M., Sigalov, P.S. (1974). Sravnitelnaya grammatika slavyanskih yazıkov. Tartu: TGU.

Grutso, A.P. (2004). Staroslavyanskiy yazık. Minsk: Tetra Sistems.

İvanova, T.A. (2005). Staroslavyanskiy yazık. S-Peterburg: Avalon/Azbuka - Klassika.

Lehfeldt, Werner; Altmann, Gabriel. (2002). "Padeniye redutsirovannıh v svete zakona P. Mentserata." Russian Linguistics 26, Netherlands: Kluwer Academic Publishers, s. 327-344.

Lehfeldt, Werner; Altmann, Gabriel, "Protekaniye padeniye redutsirovannıh v drevnerusskom yazıke svete zakona Piotrovskih", Russian Linguistics 27, Kluwer Academic Publishers, Netherlands, s. 141-149, 2003.

Lunt, Horace G. (1974). Old Church Slavonic grammar. The Hauge-Paris: Mouton.

Musatov, V.N. (2012). Russkiy yazık. Fonetika. Fonologiya. Orfoepiya. Grafika. Orfografiya. Moskva: Flinta.

Popov, M.B. (2015). "K voprosu o padenii redutsirovannıh glassnıh $\mathrm{v}$ drevnerusskom yazıke: hronologiya, fonologiçeskiy mehanizm, otrajeniye v pamyatnikah”, Uçenıye zapiski Kazanskogo universiteta 157/5, Kazan: KGU, s. 47-67.

Şahmatov, A.A. (1915). Oçerk drevneyşego perioda russkogo yazıka. Entsiklopediya slavyanskoy filologii, Petrograd: İmperatorskaya Akademiya Nauk.

Şahmatov, A.A. (1916). Vvedeniye v kurs istorii russkogo yazıka. Petrograd: Nauçnoye delo.

Şamanova, M.V., Talitskaya, A.A. (2018). Fonetika russkogo yazıka. İstoriçeskiy i sinhroniçeskiy aspektı. Yaroslavl: YarGU, 2018.

Trubetskoy, N.S. (1987). "O zvukovıh izmineniyah russkogo yazıka i raspade obşçerusskogo yazıkovogo yedinstva”, İzbrannıye trudı po filologii, Moskva: Proress, s. 143-167.

Zaliznyak, A.A. (2004). Drevnenovgorodskiy dialekt. Moskva: Yazıki Slavyanskoy Kulturı.

Zaliznyak, A.A. (1992). "Padeniye redutsirovannı po dannım berestyanıh gramot.” Rusistika segodnya. Funktsionirovaniye yazıka: leksika i rammatika, Moskva, s.82-105.

Vigotskiy, L. S. (2018). Psihologiya iskusstva. Moskva: Ripolk-Klassik. 
Sidorov, V.N. (1966). İz istorii zvukov russkogo yazıka, Moskva: Nauka.

Rusinov, N.D. (1979). Evolyutsiya i predistoriya russkogo yazıkovogo stroya, Gorkiy: GGU.

Markov, V.M. (1964). K istorii redutsirovannıh glasnıh v russkom yazıke, Kazan: KGU.

Levitskiy, V.V. (2007). Kvantitativnıye metodı v lingvistike, Vinnitsa: Novaya Kniga. 